\section{THE NATURE AND TREATMENT OF AMENTIA.}

By Dr. L. Pierce Clark, assisted by the Staff of the Psycho-Analytic Sanatorium at Rye, N.Y.

Ballière, Tindall and Cox. London. 1933.

pp. xvi+306. Price 12s. 6d.

This book approaches the subject of Mental Deficiency from an entirely new standpoint, namely, that of the thoroughgoing Freudian psycho-analyst. For the information of those who are not familiar with them, the first chapter is devoted to a brief outline of the main tenets of this doctrine. This is followed by chapters dealing respectively with the problem of mental arrest, feeblemindedness, secondary amentia, the social behaviour of the ament, the present and future outlook with regard to treatment, and, finally, a short glossary of psycho-analytic terms.

A considerable amount of the book is taken up with a description of patients and an attempt to interpret their amentia in terms of the Freudian doctrine. Thus, whilst admitting that mental arrest may have as its basis inadequate neuronic development, the main thesis of the author is that such a lesion is not the direct cause of the defect, but that it acts by crippling mental development "through its burden of handicap upon the ego and the libidinal processes necessary for mental growth and functioning". A typical example of this point of view is the author's interpretation of the cause of the defect of "Harry", a description of whom occupies twelve pages. Dr. Clark says, "As for his feeblemindedness, we may point to three conditions which seem to have a bearing. First, in passing from the oral ingestion of mother Harry appears to have remained fixed to a great extent upon the taking in of other concrete objects. A wide displacement to the ingestion of ideas, abstract conceptions, understanding, etc., seems not to have taken place. Instead, according to our impressions, the oral grasping is chiefly concerned with candy, physical rewards and presents. Again, his projections towards reality have been seen to be largely on the basis of 'doing things for mother'-that is, for the return to the secondary narcissism rather than for an objective experiencing which may absorb identifications and strengthen the ego's comprehension of reality. Finally, this inability (fear) to voyage into the outer world for a checking of inner concepts has apparently kept him back from fully grasping the nature of the real world."

Whether Dr. Clark's explanation of the cause of Amentia will be regarded as satisfying will, of course, depend upon the reader's view as to the validity of the Freudian hypothesis. Ardent disciples may conceivably regard the book as a useful addition to their knowledge; non-Freudians will probably consider its perusal a waste of time. With regard to treatment, there is no evidence that the various defective children who have been subjected to these psycho-analytical investigations are in any way the better for them-a negative result which would probably be expected by most people with extensive practical acquaintance of the condition.

\section{PSYCHOLOGY AND PSYCHOTHERAPY.}

\section{By William Brown. Third Edition.}

London : Edward Arnold \& Co. 1934.

Pp. vi. +252 .

12/6d.

The third edition of Dr. Brown's Psychology and Psychotherapy, which has just been published, has been so thoroughly revised and amplified that it is practically a new book. It is concerned more with psychotherapy than with psychology, as is obvious from the titles of the chapters-the present importance of psychology and psychotherapy, dissociation, multiple personality, dreams, the unconscious, theories of emotion, the psycho-neuroses of war, the psychotherapeutic treatment of alcoholism, adolescence suggestion, hypnotism, faith, personal influence, the psychology of peace and war, the relation of mind to brain, and psychical research. The style is popular and personal, for it abounds in references to the author's own practice and experience. It is more than a series of essays on psychotherapy written in popular language for the physician and the layman; it ranges over the fields of psychology, psychotherapy, philosophy, religion and psychical research, and conveys to the reader much of his philosophy of life, for Dr. Brown is a 
psychologist and philosopher as well as a psychotherapist. His ideals of the duty of a psycho-analyst are high. "It is," he says, "the function of a successful analyst to be able to evoke complete sincerity on the part of the patient, and to call out his respect for ultimate values and clear the way for the development of a life that is spiritual at its highest, that has a love for good to the fullest extent possible for the individual."

Dr. Brown succumbs to the fashionable practice of adding in appendices reprints of papers already published. There are five appendices to this book; one describes three cases of war neurosis, one gives a record of a deep mental analysis, and the other three are on mathematical topics, the mathematical and experimental evidence for the existence of a central intellective factor $(g)$, a test of the theory of two factors, and a comparison of the theory of two factors with the sampling theory, in relation to the data of Appendix IV. They are all interesting and valuable contributions to either psycho-therapy or statistical psychology ; but one wonders why the last three have been included, for, though there is great need in psychotherapy, as in all forms of therapy, for the application of objective statistical analysis of the data which have given rise to the present welter of theory, the author gives in this book no indication of having applied such analysis to psycho-therapeutic material: perhaps they are included because the word "psychology" appears in the title and these are matters of interest to psychologists. Dr. Brown has made so many notable contributions to statistical science that one would welcome from him an attempt to oust anecdote and rhetoric from the discussion of psychiatric material and to substitute for it the objective methods of statistical science.

\section{Miscellaneous.}

\section{FAT EMULSION AS A FACTOR IN INFANT FEEDING.}

It is quite evident that all the constituents present in an infant food must be of complete utility in the nutrition Trufood of the young child and upon the easy and complete digestion of these various constituents will depend their ready assimilation.

The fat constituent must play an important part in the question of diet, not only on account of its high calorific value, but also because it is usually the only source of those Vitamins which concern or regulate growth and provide protection against bacterial infection in the young child by maintaining healthy conditions.

It is necessary, therefore, that in the manufacture of an infant food on a Cows' Milk basis, two conditions should always be fulfilled.

1. The natural colloidal and emulsifying properties of the protein should remain unaltered.

2. The fatty constituent should, on reconstitution with water, be found in the form of a fine and stable oil-in-water emulsion.

It is well-known that the colloidal properties of the protein in milk are very susceptible to the process of drying. Apart from the adverse effect of high temperature $\left(170^{\circ} \mathrm{F}\right.$. or above), the protein is readily de-natured by passing through that stage of moisture elimination, at which the water content is reduced to between 8 and 10 per cent. Unless this stage is passed instantaneously, de-naturation and loss of colloidal properties occurs, even if the stage only persists for a few seconds.

It is quite impossible, when drying at high temperature, to avoid the required time-exposure to this particular moisture content, and hence arise the insolubility and loss of colloidal properties of the protein so characteristic of milks dried by the usual processes at high temperatures.

In Spray Drying, however, the exceedingly fine droplets of the mist of liquid milk so formed, undergo instantaneous desiccation, and the danger zone of moisture content is passed so rapidly that de-naturation cannot occur. As a consequence, when spray-dried milks are re-constituted with water, the protein again appears in its original colloidal and undamaged state, and with its full stabilising powers for the fat emulsion. At the same time, the action of the Spray is to still further divide the original fat globules, and so improve both the emulsion and its stability. 